\title{
STRESZCZENIE
}

Artykuł dotyczy porównania poezji Romana Honeta i malarstwa Zdzisława Beksińskiego. Wychodząc od ogólnych podobieństw pomiędzy tymi twórcami, polegających na obecności w ich dziełach estetyki groteski, fantastyki, oniryzmu i surrealizmu, wskazane zostają bardziej szczegółowe podobieństwa. Obu artystów można sytuować w obszarze twórczości fantastycznej, w której ważną rolę odgrywa włączanie w obraz elementów cudownych i niesamowitych, spójne imaginarium i zniekształcające przedstawienie techniki twórcze. Zarówno Honet, jak i Beksiński niechętnie tłumaczą znaczenie swoich dzieł, pozostawiając odbiorcy dowolność skojarzeń lub podkreślając intuicyjny charakter procesu twórczego. Za pomocą przedstawień antropomorficznych hybdryd obaj twórcy wskazują na złożony status bytów nie-ludzkich, a co za tym idzie, również samego człowieka, w którym łączy się to, co zwierzęce, i to, co społeczne.

\section{Slowa kluczowe}

Roman Honet, poezja polska, wyobraźnia, Zdzisław Beksiński, transdyscyplinarność, intermedialność 


\section{S UM M A RY}

\section{Roman Honet and Zdzisław Beksiński - a Fellowship of Fantastic Imagination}

The article compares the poetry of Roman Honet and the paintings of Zdzisław Beksiński. Departing from the general similarities between the artists, consisting in the presence of the aesthetics of the grotesque, fantasy, oneirism and surrealism, the author outlines some more specific similarities. Both artists, for instance, can be situated in the field of fantasy art, in which an important role is played by the incorporation into the image of miraculous and fantastic elements, a coherent imaginarium and creative techniques distorting the representation. Both Honet and Beksiński are reluctant to explain the significance of their works, giving the recipient the freedom to make associations or emphasising the intuitive nature of the creative process. Using representations of anthropomorphic hybrids, both artists point to the complex status of non-human entities, and hence also to the human being, in which the animal and the social are combined.

\section{Keywords}

Roman Honet, Polish poetry, imagination, Zdzisław Beksiński, transdisciplinarity, intermediality

Cechą charakterystyczną poezji Romana Honeta jest jej „obrazowość” 1 i „wizyjność" ${ }^{\prime}$, przez co należy rozumieć wykorzystywanie opisu skupionego na jakościach wzrokowych ${ }^{3}$. Marian Stala mówi wręcz o strategii twórczej, którą nazywa „nastawieniem na obraz”. Wiersze Honeta są bogate w opisy wywołujące wrażenia wizualne, które swoją konwencją odsyłają do estetyki fantastycznej, groteskowej, onirycznej czy surrealistycznej. Wielokrotnie w jednym utworze dochodzi do nagromadzenia obrazów układających się w sekwencje, czasem spojonych za sprawą dysponującego wizjami podmiotu, którego obecność bywa subtelnie zaznaczona:

teraz biegnij przez sklepy,

lecz mnie nie zabieraj. przez porę

psychopatów zaplątanych w kablach, czaszki wariatów w perukach,

1 ,Są wreszcie tacy poeci nieobliczalni i osobni jak Honet, którzy w mniejszym stopniu zaufali fascynacji zbitkami słownymi i nie dali się uwieść frazeologicznym grom, lecz raczej skierowali swoją uwagę na obraz, siłę wewnętrznych pejzaży o neurotyczno-nadrealistycznej proweniencji”. K. Maliszewski, Głosy z „bezbrzeżnej podróży”, [w:] tenże, Rozproszone głosy. Notatki krytyka, Warszawa 2006, s. 251.

2 „Poeta ten - bardziej szaman niż retor - oddaje się przyjemności mieszania obrazów najodleglejszych, byle tylko osiągnąć olśniewający efekt napięcia między dźwiękiem a wizją". J. Winiarski, Te ciche spazmy o podartych włóknach, "Kwartalnik Artystyczny” 1997, nr 2, s. 35.

${ }^{3}$ Seweryna Wysłouch definiuje obrazowość literatury jako "szczególną zdolność dzieł literackich do tworzenia przedstawień bogato wyposażonych w jakości zmysłowe i do wywoływania u czytelnika wrażeń wizualnych, dotyczących koloru, kształtu, walorów przestrzennych". Zob. S. Wysłouch, «Ut pictura poesis» - stara formuła i nowe problemy, [w:] Ut pictura poesis, red. M. Skwara, S. Wysłouch, Gdańsk 2006, s. 12.

${ }^{4}$ M. Stala, Nocna alchemia, „Tygodnik Powszechny” 2008, nr 36, s. 36. 
pijących limfę i kwas fosforowy, tankowce przewożące $\mathrm{w}$ płynie święte obrazy. [tekst skażony]. biegnij

poprzez akwaria do przewozu chmur, na targi krwi - stoiska z używaną żywnością z francji i niemiec. lato, jeśli nadejdzie, może się wycofa zbliży się anioł z dźwiękoszczelną włócznią, pszczoły jak złote skrzepy w termometrze, aby stało się zimno. tak zimno od lat

(idź poprzez sklepy, cp, s. 22) ${ }^{5}$

Biorąc pod uwagę doznania wzrokowe, można stwierdzić, że wiersz zawiera wiele typowych dla poetyki Honeta przedstawień, takich jak groźne lub niepokojące postaci, często wyposażone w rekwizyty i atrybuty wzmacniające ich odrażający wygląd. W wierszu są to psychopaci zaplątani w kable, o „czaszk[ach] wariatów w perukach”, „pijących limfę i kwas fosforowy”. Charakterystyczna jest również „płynna” metaforyka, w wierszu reprezentowana przez obrazy limfy, kwasu fosforowego, tankowców wypełnionych płynem, akwariów i skrzepów. Równie typowa jest w idź poprzez sklepy obecność obrazów, których treść odwołuje się do religii (święte obrazy przewożone $\mathrm{w}$ płynie, anioł). W wierszu pojawiają się również powracające w twórczości Honeta motywy zwierzęce (pszczoły), letnie lub zimowe krajobrazy. Choć sięganie do stałego repertuaru ulubionych przez poetę motywów naraża go na zarzuty o powtarzalność, to ograniczenie się w doborze środków zapewnia tej dykcji wyrazistość i rozpoznawalność. Może to stanowić zaletę, umacniającą pozycję Honeta jako „wyobraźniowca", jednak ma znaczenie również ze względu na problem wizualności. Wykorzystywanie powtarzających się obrazów poetyckich buduje bowiem świat w jakimś sensie skończony i zamknięty, co ułatwia czytelnikowi jego przyswojenie. Przeczytawszy tom lub dwa, przed lekturą każdego kolejnego wiersza dysponuje on gotowymi, czekającymi w pogotowiu „wyglądami”. Roman Ingarden pisał, analizując budowę dzieła literackiego:

[...] wyglądy nie łączą się na ogół ze sobą w całość ciągłą, wypełniając bez przerwy wszystkie fazy utworu od początku do końca. Raczej pojawiają się od czasu do czasu, jakby rozbłyskując na chwilę i przygasając wraz z przejściem czytelnika do następnej fazy utworu. W samym dziele znajdują się jakby „w pogotowiu”, w stanie pewnej potencjalności. Mogą one przynależeć do różnych zmysłów, a nawet być pozazmysłowymi, choć niemniej naocznymi „zjawiskami” tego, co psychiczne ${ }^{6}$.

${ }^{5}$ Przywołując wiersze Honeta, posługuję się następującymi skrótami: m - moja, Wrocław 2008; bs - baw się, Wrocław 2009; pk - piąte królestwo, Wrocław 2011; sbm - świat byt mój, Wrocław 2014; cp - ciche psy, Stronie Śląskie 2017.

${ }^{6}$ R. Ingarden, Dwuwymiarowa budowa dzieła sztuki literackiej, [w:] tenże, Szkice z filozofii literatury, Kraków 2000, s. 28. 
Wywód Ingardena dotyczy „specjalnej odmiany świadomości”, ",spostrzegania" i „doznawania wyglądu" mówi się o percepcji czytanego tekstu, którego odbiorca stwarza modele umysłowe ${ }^{8}$. W nieco bardziej metaforyczny sposób zjawisko określa Gaston Bachelard, definiując obraz poetycki jako "nagły wykwit psychiki, wykwit, którego determinanty psychologicznie niełatwo zgłębić" ${ }^{\prime 9}$.

Równie spójny świat prezentuje w swojej twórczości Zdzisław Beksiń$\mathrm{ski}^{10}$. Zainteresowania Beksińskiego były dosyć zróżnicowane, bo oprócz malarstwa zajmował się on rysunkiem, fotografią, rzeźbą i grafiką komputerową, jednak we wszystkich jego pracach powracają pewne charakterystyczne motywy. Jest to szczególnie widoczne na obrazach olejnych z tzw. okresu fantastycznego, tworzonych w latach 1963-1983. Tadeusz Nyczek $\mathrm{w}$ następujących słowach charakteryzuje tworzone w tym czasie przez Beksińskiego dzieła:

Od 1974 roku Beksiński maluje wyłącznie obrazy. [...] wciąż prawie to samo i prawie tak samo. Są to mianowicie, naprzemiennie powracające w różnych odstępach czasu, niemalże stałe motywy: głów bądź postaci obleczonych łuszczącą się skórą-pajęczyną, twarzy z profilu w hełmach kutych w najprzeróżniejsze wzory, biblijnych Ukrzyżowań, płonących domów-katedr, obiektów lecących w powietrzu, trupio podobnych stworów pełzających po ziemi, hieratycznie usadowionych postaci „królów" udrapowanych w fantastyczne szaty, pejzaży morskich bądź łąkowych z motywami pojedynczych drzew, nagrobków lub postaci usadowionych na krześle $\mathrm{e}^{11}$.

Zarówno Beksiński, jak i Honet, za sprawą powtórzenia pewnych motywów tworzą spójny, charakterystyczny świat. Obaj sięgają po podobnie groteskowe przedstawienia, których nagromadzenie w twórczości oceniać można jako manieryczne lub pretensjonalne.

W wypowiedzi Nyczka zostało wskazane kilka istotnych z perspektywy porównawczej cech malarstwa Beksińskiego z okresu „fantastycznego". Artysta widział w przekładającym się na anegdotyczny charakter obrazów z tego okresu nagromadzeniu elementów „po prostu potrzeb[e] namalowania czegoś w każdym fragmencie obrazu"12. Niemniej ilość elementów umieszczonych na obrazie pozwala jednak na większe możliwości interpretacyjne, poszukiwanie inspiracji, symboli, wewnętrznych powiązań, a w efekcie tworzenie przez oglądającego pewnej opowieści.

\footnotetext{
7 Tamże, s. 26-27.

${ }^{8}$ R.J. Sternberg, Psychologia poznawcza, przeł. E. Czerwińska, A. Matczak, Warszawa 2001, s. 121.

${ }^{9}$ G. Bachelard, Wyobraźnia poetycka. Wybór pism, przeł. H. Chudak, A. Tatarkiewicz, Warszawa 1975 , s. 369.

${ }^{10}$ Andrzej Jarosz pisze o „fantastycznym uniwersum”. Zob. A. Jarosz, Beksiński i źródła wyobraźni, „Poznańskie Studia Polonistyczne” 2016, nr 28 (48), s. 211.

${ }^{11}$ T. Nyczek, Zdzisław Beksiński, Warszawa 1989, s. 14.

12 Tamże, s. 11.
} 


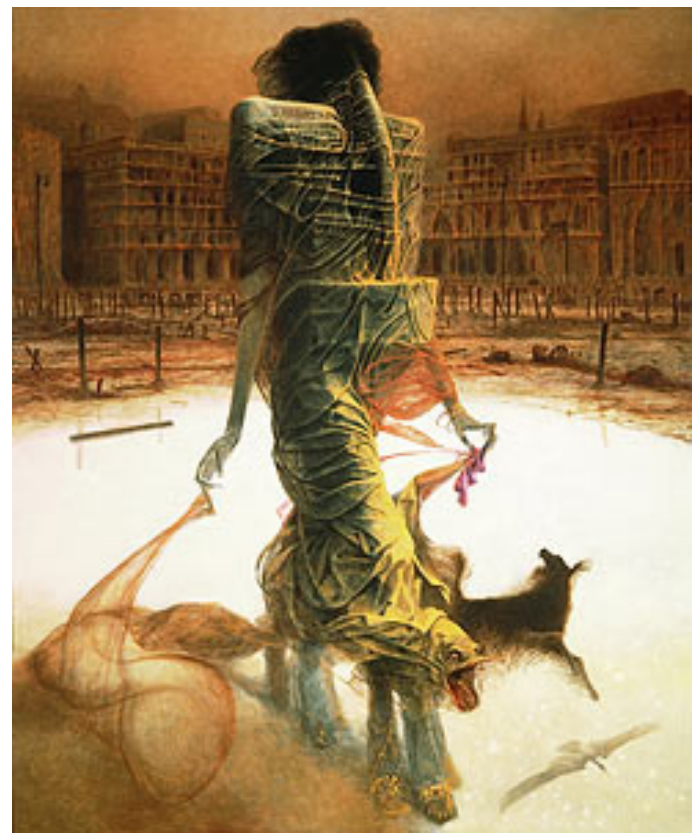

Ilustracja 1. [DG-2455], 1981, olej na płycie pilśniowej, 73 × 87 cm³

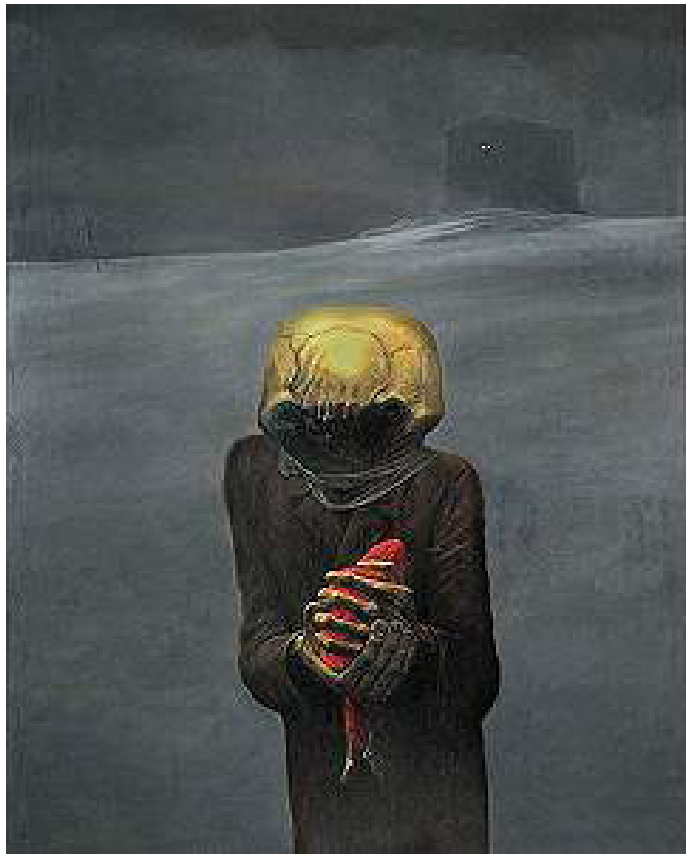

Ilustracja 2. [DG-2241], 1972, olej na płycie pilśniowej, 100 x 122 cm

${ }^{13}$ Zbigniew Beksiński nie tytułował obrazów, dlatego podpisuję je oznaczeniami ze strony Piotra Dmochowskiego, z której korzystam: http://beksinski.dmochowskigallery.net/ galeria_karta.php?artist $=52 \&$ picture $=2455$ [dostęp 20.04.2021]. 
Piotr Dmochowski zauważa, że w tym okresie aspekty formalne mniej interesowały Beksińskiego: „Najważniejsza była wówczas dla niego atmosfera, którą chciał stworzyć w każdym obrazie, oraz żart, persyflaż czy malarska aluzja, którymi ozdabiał prawie każdy z nich w tamtych czasach. To wszystko wyrażał rekwizytami oraz kolorami, do których się uciekał"14. Waldemar Siemiński pyta z kolei: „Czy jest, jak mu zarzucają, zbyt literacki? Jeśli literatura jest fabułą i akcją, to czy Beksiński jest do opowiedzenia? ${ }^{15 \prime}$. Rzeczywiście, jeżeli za literaturę uznać fabułę i akcję, to Beksiński nie jest „do opowiedzenia”. Inaczej jest jednak, gdy porównujemy obrazy sanockiego malarza z poezją. Fabuła i akcja nie mają tam takiego znaczenia jak sam obraz poetycki czy opis. W języku krytyki, stosowanym do opisu utworów Honeta i dzieł Beksińskiego, widoczne są odniesienia do odrębnych dziedzin sztuki. W przypadku poezji mówi się o "obrazie”, czy też „wizji”, opisując malarstwo, krytycy sięgają po określenia „opowieść" i „symbol”.

\section{Fantastyka}

Honeta nazywa się twórcą reprezentującym nurt „ośmielonej wyobraźni”16 $\mathrm{i}$ „imaginatywistą". Tym ostatnim pojęciem Magdalena Rabizo-Birek określa twórczość, którą cechuje spotęgowana figuratywność i meliczność języka, powrót do wiersza rytmicznego, gry językowe, zwracanie uwagi na kształt wizualny wiersza, antyestetyzm, ekspresjonizm i, co ważne, synestezja oraz typ kreacyjnej wyobraźni - fantastyczno-groteskowej i oniryczno-surrealistycznej ${ }^{17}$. Trzeba zauważyć, że samo określenie „wyobraźnia wyzwolona” (lub „ośmielona”) bywa postrzegane jako termin zbyt ogólny lub po prostu redundantny, gdyż, jak zauważa Marcin Orliński, „,wyobraźnia i poezja w jednym stały domu”. Autor przypomina, że wyobraźnia jest pojęciem często używanym przez krytykę, wskazując, jak różne i odległe w czasie

${ }^{14}$ P. Dmochowski, Sale muzealne. Sala 10. Obrazy. Lata 1968-1983. Objaśnienie, http://beksinski.dmochowskigallery.net/galeria.php?artist=52 [dostęp 20.04.2021].

${ }^{15}$ T. Nyczek, Zdzisław Beksiński..., s. 96.

${ }^{16}$ Zob. S. Trusewicz, Wyobraźnia wyzwolona i oko Romana Honeta, [w:] Wyobraźnia przestrzenna w perspektywie geopoetyki, red. E. Konończuk, K. Trusewicz, S. Trusewicz, Białystok 2018. W artykule przypominam historię pojęcia „ośmielonej wyobraźni”, odnosząc je do twórczości poety. Na temat Romana Honeta jako reprezentanta nurtu „ośmielonej wyobraźni" zob.: M. Stala, Czy coś się zaczyna? Z Marianem Stalą o zjawisku najmłodszej polskiej poezji rozmawia P. Marecki, [w:] Tekstylia. O „rocznikach siedemdziesiątych”, wyb. i oprac. P. Marecki, I. Stokfiszewski, M. Witkowski, Kraków 2002; M. Orliński, Sprawa wyobraźni, http:// members.upcpoczta.pl/m.orlinski4/sprawawyobrazni.htm [dostęp 30.03.2021]; M. Jurzysta, "Ośmielanie wyobraźni" w najnowszej poezji polskiej, [w:] Inne dwudziestolecie. Dwudziestolecie literackie 1989-2009, t. II, red. Z. Andres i J. Pasterski, Rzeszów 2010; F. Materkowski, Od wyzwolonej do ośmielonej wyobraźni, czyli o poetyce imaginatywistów polskich, [w:] Wyobraźnia poetycka XXI wieku, red. A. Czabanowska-Wróbel, M. Marchaj, Kraków 2014; M. Peroń, Świat w rozkładzie. O nurcie „ośmielonej wyobraźni” roczników 70. (Roman Honet, Bartłomiej Majzel, Radosław Kobierski), [w:] Literatura na progu XXI wieku, red. J. Chłosta-Zielonka, Z. Chojnowski, Olsztyn 2014.

${ }_{17}$ M. Rabizo-Birek, Bruno Schulz poetów „ośmielonej wyobraźni” (preliminaria), „Schulz/ Forum" 2019, nr 13, s. 69. 
dzieła się nim opisuje ${ }^{18}$. Motywy surrealistyczne, groteskowe i oniryczne łatwo wskazać również w malarstwie Beksińskiego. Krytykom sztuki zdarzyło się dostrzec w nim jednak kicz, infantylność czy patos ${ }^{19}$, co wynikać może z niedowartościowania sztuki fantastycznej, która, jak zauważa Aneta Grodecka, „funkcjonuje na pograniczach «dobrego smaku»"20. Badaczka, zaliczając Beksińskiego do grona reprezentantów nurtu fantastycznego, definiuje ten kierunek jako kojarzony ze stałymi motywami,

których rejestr obejmuje charakterystyczne miejsca (miasta, podwodna głębia, podziemie, kosmos) i postaci (stwory baśniowe, mitologiczne, harpie, sfinksy, duchy i zjawy, hybrydy, Obcy). Fantastyka to model obrazowania uwzględniający zasady prawdopodobieństwa, oparty na spójnej, jednolitej motywacyjnie wizji świata. Dzieła tego nurtu wywołują w przestrzeni odbioru poczucie niesamowitości. Na poziomie formy dominuje technika iluzjonistyczna, poparta wirtuozerią warsztatową; to przedstawienia z wyraźną narracją, z napięciem temporalnym, splotem anachronizmu i wizjonerstwa ${ }^{21}$.

Ustalenia badaczki opierają się po części na pracy Rogera Caillosa, który pisał, że fantastyka ,jest zerwaniem z ustalonym ładem, wkroczeniem do niezmiennej legalności dnia tego, co niedopuszczalne, a nie zastąpieniem świata realnego przez świat wyłącznie cudowny"22. Wśród odbiorców poezji Honeta pojawiają się określenia bliskie kategorii fantastyki, takie jak „nadrealizm” i „niesamowitość" ${ }^{23}$. W związku z problemem w definiowaniu fantastyki, która obejmuje szereg różnych realizacji „cudowności”24, poezję Honeta i malarstwo Beksińskiego należy traktować zgodnie

${ }^{18}$ M. Orliński, Sprawa wyobraźni... Jakub Skurtys posługując się w swojej krytyce pojęciem „ośmielonej wyobraźni”, określa je epitetami „przemielonej”, „niesławnej”, czy porównując ją do odgrzewanego, ale „przesmacznego kotleta”, czym wskazuje zarówno na popularność i atrakcyjność konwencji wśród poetów najnowszych, jak i samą problematyczność kategorii. Zob. J. Skurtys, J. Nowacki, Niech im się śni po nocach, „Mały Format” 2019, nr 12, http://malyformat.com/2019/12/im-sie-sni-nocach/ [dostęp 14.04.2021]; J. Skurtys, Krytyka negatywna (4): oślepta, „Mały Format” 2017, nr 9, http://malyformat.com/2017/09/krytyka-negatywna-4-oslepla/ [dostęp 14.04.2021]; tenże, Wyobraź to sobie sobie, "Wakat”, http://wakat. sdk.pl/wyobraz-to-sobie-sobie/ [dostęp 14.04.2021].

19 „Malarstwo Beksińskiego stało się zapisem maniakalnych wizji, często balansujących na granicy kiczu” (A. Rottenberg, Sztuka w Polsce 1945-2005, Warszawa 2005); "mozolnie, z dbałością o iluzję maluje infantylne wizje zjawisk nadprzyrodzonych" (Ł. Gorczyca, M. Kaczyński, Stowniczek artystyczny Rastra, http://raster.art.pl/archiwa/slownik/slowniczek.htm [dostęp 14.04.2021]); ,_[...] Beksiński był malarzem fatalnym. Dosłownym, patetycznym, przewidywalnym, wtórnym, infantylnym", J. Banasiak, Zdzisław Beksiński jako totalne dzieło sztuki, "Szum", https://magazynszum.pl/zdzislaw-beksinski-jako-totalne-dzielo-sztuki/ [dostęp 14.04.2021]).

${ }^{20}$ A. Grodecka, Fotografie nieistniejącego świata. O polskiej sztuce fantastycznej, „Poznańskie Studia Polonistyczne" 2016, nr 28 (48), s. 55.

${ }^{21}$ Tamże, s. 67-68.

${ }^{22}$ R. Caillois, W sercu fantastyki, przeł. M. Ochab, Gdańsk 2005, s. 149.

${ }^{23}$ M. Jurzysta, Jak i dlaczego ośmielała się wyobraźnia, [w:] Bowiem zmarli podróżuja szybko. Szkice o twórczości Romana Honeta, wyb., red. Z. Sala, Kraków 2020, s. 20, 43.

${ }^{24}$ Małgorzata Niziołek jako nadrzędną wobec fantastyki kategorię wskazuje surnaturel (nadnaturalność), którego realizacjami są fantastyka, merveilleux, science fiction, fantasy, magie. 
z definicją Grodeckiej, koncentrując się na wymienionych przez badaczkę zabiegach formalnych, takich jak: nagromadzenie elementów, zaburzenie proporcji, monstrualizacja kształtów, wydłużanie sylwetek, zasada reifikacji, zestawianie, „lepienie” elementów, wykorzystanie zwyczajnego przedmiotu w funkcji magicznej ${ }^{25}$.

\section{Znaczenie}

Zarówno Honet, jak i Beksiński są znani z niechęci do egzegetycznych interpretacji swoich dzieł. Poeta mówił: „wątpię w sens wyjaśniania własnych wierszy. Dla mnie to po prostu nie honor. Wobec czytelnika"26. Malarz deklarował w podobnym tonie: „nie chcę tym niczego przekazać, bo nie mam niczego do przekazania" ${ }^{\prime 2}$. W sugestywnie zatytułowanej rozmowie ze Zbigniewem Taranienką, Znaczenie jest dla mnie bez znaczenia, Beksiński mówił o swoim podejściu do interpretacji: „Chciałbym tę wizję namalować tak, jak jawi się w umyśle - bez analizy znaczeń i bez stosowania przenośni"28. Podobnej postawy przy odczytywaniu swojej sztuki zdawał się również oczekiwać od krytyków, mówiąc z irytacją:

Cały czas maluję obraz, oczywiście nie uciekam od nastroju, od atmosfery, bo lubię pewne określone atmosfery, a pewnych innych atmosfer czy nastrojów nie lubię. Tym niemniej nie mogę zgodzić się, gdy mi ktoś bez przerwy zarzuca... albo charakteryzuje moje wizje według własnych upodobań i jeszcze ma pretensje ${ }^{29}$.

Maluję je [obrazy - przyp. S.T.] całkowicie naiwnie, podobnie jakbym fotografował własne sny. Pomysły przychodzą mi do głowy w ułamku sekundy i nie widzę żadnego powodu po temu, by je oceniać jako mądre, głupie, moralne, niemoralne, budujące lub destrukcyjne ${ }^{30}$.

Z wypowiedzi Beksińskiego odczytać można niechęć do „hermeneutyki podejrzen" ${ }^{\prime \prime}$. Od krytyków oczekiwał koncentracji na aspektach formalnych dzieła, stwierdzając, że „odżegnuje się od wszelkich treści, jeżeli

Zob. M. Niziołek, Zdefiniować fantastyke, czyli "fantastyczne" (i nie tylko) teorie literatury fantastycznej, „Przestrzenie Teorii” 2005, nr 5.

25 Tamże, s. 68.

${ }^{26} \mathrm{R}$. Honet, To ja posadziłem palmy $i$ wybrałem matpy. Z Romanem Honetem o książce piąte królestwo rozmawia Konrad Wojtyła, „biBLioteka. Magazyn Literacki”, https://www.biuroliterackie.pl/biblioteka/wywiady/to-ja-posadzilem-palmy-i-wybralem-malpy/ [dostęp 28.04.2021].

${ }^{27}$ Z. Korus, Zdzisław Beksiński, „Sound and Vision” 2001 (grudzień), nr 8, s. 110.

${ }^{28}$ Z. Taranienko, Znaczenie jest dla mnie bez znaczenia (Zdzisław Beksiński), [w:] tenże, Rozmowy o malarstwie, Warszawa 1987, s. 189.

${ }^{29}$ M. Skarzyńska, Z. Beksiński, Wszystko, co jest forma, może podlegać deformacji, "Akcent” 2006, nr 4, s. 107.

${ }^{30}$ Z. Beksiński, Okrucieństwo? Pornografia? Sztuka?, „Kultura” 1974, nr 46, s. 11.

${ }^{31}$ Zob. P. Ricoeur, O interpretacji. Esej o Freudzie, przeł. M. Falski, Warszawa 2008. Beksiński niechętnie odnosił się również do psychoanalitycznych analiz swoich dzieł. 
idzie o obrazy"32. Zgodziłby się zapewne z Susan Sontag, która przyczyny dominacji interpretacji doszukiwała się właśnie w prymacie treści nad formą ${ }^{33}$. Krytyczka mówiła obrazowo:

Niczym spaliny i fabryczne wyziewy zatruwające miejskie powietrze, erupcje interpretacji dzieł sztuki zatruwają dziś naszą wrażliwość. W kulturze, której zasadniczym problemem jest nadmierny rozrost intelektu dokonujący się kosztem świeżości i zdolności odczuwania, interpretacja stanowi zemstę intelektu na sztuce ${ }^{34}$.

Mimo że zarówno Sontag, jak i Beksiński postrzegają treść i formę, jak również kategorię mimesis nieco schematycznie ${ }^{35}$, oboje zdają się dopominać o interpretację ikoniczną, niepodporządkowaną zwrotowi językowemu spod znaku Ferdinanda de Saussure'a ${ }^{36}$.

Wypowiedzi Honeta również sytuują go w gronie „przeciwników interpretacji”, o czym świadczy jego odpowiedź na pytanie o analogię piątego królestwa z piątym kręgiem piekielnym Dantego:

Szukanie analogii to zawsze było wygodne zajęcie, dla części współczesnych humanistów stało się czarująco obowiązkowe. Potrafią znaleźć związek między cyklem menstruacyjnym pigmejki a wybuchami supernowych, co Alan Sokal i Jean Bricmont perfekcyjnie wydrwili w Modnych bzdurach, używając porównywalnie niedorzecznych przykładów ${ }^{37}$.

Również krytycy tej poezji zdają się postrzegać ją jako trudną do odczytywania za pomocą tradycyjnych kategorii. Marcin Sierszyński pisze o rezygnacji ze śledzenia "tropów” i „znaczeń", gdyż te albo „ciągle się gubią", albo pozostają „,niepewne” ${ }^{\prime 38}$, w czym również można dostrzec tendencję ikonicznego pojmowania literatury. Meliczność poezji Honeta, na którą zwróciła uwagę Rabizo-Birek, można rozumieć metaforycznie, jako pewną nastrojowość, którą autor wyraża poprzez obrazy poetyckie. Byłaby to atmosfera melancholii, rezygnacji, smutku lub uspokojenia ${ }^{39}$, przechodząca w nastrój zagrożenia, zniszczenia, wściekłości i rozemocjonowania. Michał Larek pisał:

${ }^{32}$ K. Janowska, P. Mucharski, Z. Beksiński, Beksiński about inner landscapes, 2002, https:// youtu.be/MiYrn441P2U?t=77 [dostęp 28.04.2021].

${ }^{33}$ S. Sontag, Przeciw interpretacji, [w:] taż, Przeciw interpretacji i inne eseje, przeł. M. Pasicka, A. Skucińska, D. Żukowski, Kraków 2012, s. 13.

${ }^{34}$ Tamże, s. 16-17.

35 Zob. A. Kopkiewicz, Spóźniona zmysłowość i nowa wrażliwość (O «Przeciw interpretacji i innych esejach» Susan Sontag), „Wielogłos” 2012, nr 2 (12).

${ }^{36}$ Zob. A. Zeidler-Janiszewska, "Visual Culture Studies” czy antropologicznie zorientowana Bildwissenschaft? O kierunkach zwrotu ikonicznego w naukach o kulturze, „Teksty Drugie” 2006, nr 4.

${ }^{37} \mathrm{R}$. Honet, To ja posadziłem palmy $i$ wybratem matpy...

${ }^{38}$ M. Sierszyński, Genetycznie sensualna fantazja Honeta, „biBLioteka. Magazyn Literacki”, https://www.biuroliterackie.pl/biblioteka/recenzje/genetycznie-sensualna-fantazja-honeta/ [dostęp 28.04.2021].

${ }^{39}$ Zob. G. Jędrek, Romana Honeta "świat był mój", czyli uniwersum straty, [w:] Bowiem zmarli podróżują szybko. Szkice o twórczości Romana Honeta, wyb., red. Z. Sala, Kraków 2020. 
Honet daje to, czego nie potrafi dać Zagajewski, a od czego większość z nas, jak sądzę, jest uzależniona dzisiaj: pikanterię, dosadność, perwersję, okrucieństwo. Honet lepiej zaspokaja nasze zmysły, które przecież programują nasze techniki mówienia o świecie i bycia w świecie ${ }^{40}$.

Sam poeta określa swoją twórczość za pomocą muzycznej metafory: „ja tu piszę poezję, robię rock'n'rolla w pustce i kostnicach, co mnie obchodzi filozofia"41. Również Beksiński, opisując swoją technikę twórczą, sięgał po porównania muzyczne: „To co jest namalowane, nie ma dla mnie większego znaczenia. Ważne jest, jak to działa w sensie dźwięku, formy i dźwięku koloru położonych w tym, a nie innym miejscu. A więc posługuję się kształtem, ale dla celów, które nazwałbym celami muzycznymi" ${ }^{\prime 2}$. Mimo sympatii do klasycznego rocka, którego słuchał głośno podczas malowania, artysta inspirował się również muzyką klasyczną, stąd zapewne porównanie pracy malarskiej do komponowania XIX-wiecznego poematu symfonicznego, w którym ważne jest to, czego nie sposób wyrazić w słowach ${ }^{43}$.

Beksiński zwykle odżegnywał się od objaśniania znaczeń, twierdząc, że maluje w sposób bezrefleksyjny i intuicyjny. Niektóre z obrazów zdają się jednak sugerować pewien namysł, jak ten przedstawiający dwa wilki spoglądające na unoszący się balon z umieszczonym na nim słowem nevermore. Zapytany o intencję twórczą w przypadku tego dzieła, malarz przyznał, że rzeczywiście chciał wyrazić taką kompozycją pewną konkretną treść. Wyraźnie zakłopotany jej objaśnianiem, powiedział, że wilki przeżywają sytuację, która więcej im się nie przytrafi, co wyrażać ma napis umieszczony na balonie. Malarz przyznał, że ze względu na dystans czasowy nie potrafi „wprowadzić się w nastrój” i do końca wyjaśnić, jakie intencje mu towarzyszyły $^{44}$. Trzeba zauważyć, że omawiany obraz jest metaforą intuicyjnej strategii malarskiej Beksińskiego. Odlatujący balon stanowiłby obecne jedynie przez krótki czas w zasięgu percepcji wrażenie, uczucie, być może wizję, których nie sposób po przeminięciu danej chwili odtworzyć.

\section{Antropomorficzne hybrydy}

Wśród motywów obecnych zarówno w utworach Honeta, jak i obrazach Beksińskiego uwagę zwracają przedstawienia antropomorficznych hybryd ${ }^{45}$.

\footnotetext{
${ }^{40}$ M. Larek, Dlaczego potrzebny jest nam Honet?, „biBLioteka. Magazyn Literacki”, https:// www.biuroliterackie.pl/biblioteka/recenzje/dlaczego-potrzebny-jest-nam-honet/ [dostęp 30.04.2021].

${ }^{41}$ G. Czekański, R. Honet, Milczenie, powrót, dzieciństwo, https://www.biuroliterackie.pl/ biblioteka/wywiady/milczenie-powrot-smierc-dziecinstwo/ [dostęp 30.04.2021].

42 J. Czopik, Z. Beksiński, Sfotografować sen. Rozmowa ze Zdzisławem Beksińskim, „Tygodnik Kulturalny" 1978, nr 35, s. 10.

${ }^{43}$ M. Grzebałkowska, Beksińscy. Portret podwójny, Kraków 2014, s. 138.

${ }^{44} \mathrm{Z}$. Beksiński, Beksiński on the Meaning of His Art, https://youtu.be/1EsYHvVtb34?t=286 [dostęp 30.04.2021].

${ }_{45}$ Traktuję porównywane utwory w duchu transdyscyplinarności postulowanym przez Ryszarda Nycza (zob. R. Nycz, Kulturowa natura, słaby profesjonalizm. Kilka uwag o przedmiocie poznania literackiego i statusie dyskursu literaturoznawczego, [w:] Kulturowa teoria literatury, red. M.P. Markowski, R. Nycz, Kraków 2006) i stosując transdyscyplinarne kategorie, takie jak:
} 


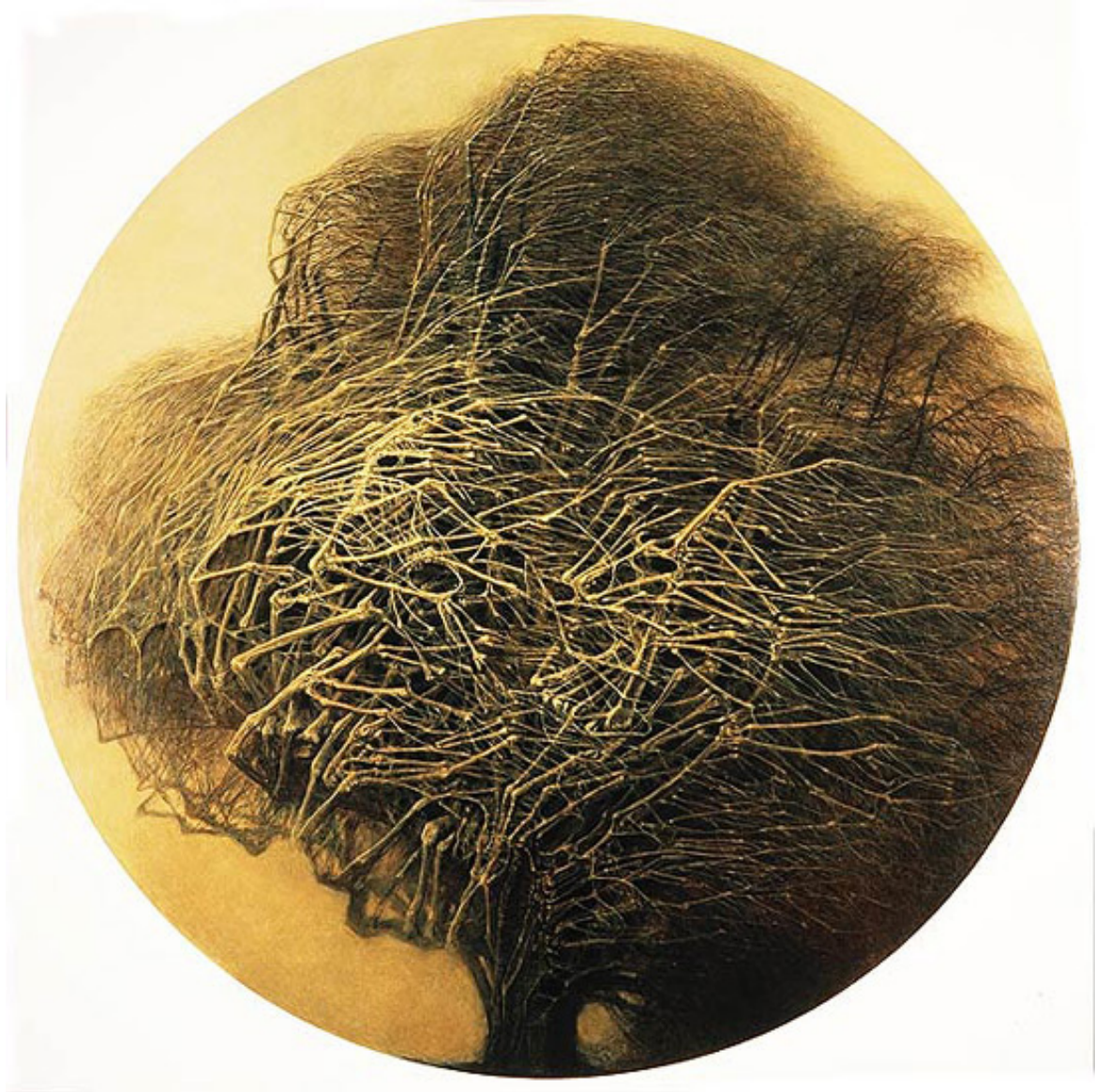

Ilustracja 3. [DG-2508], 1982, olej na płycie pilśniowej, 73 x 91 cm

Jedno z nich pojawia się $\mathrm{w}$ wierszu Honeta pod tytułem drzewo przeludnione, który proponuję zestawić z obrazem Beksińskiego z 1982 roku. Głównym tematem obu dzieł jest przedstawienie drzewa o antropomorficznych cechach. W wierszu Honeta mowa jest o twarzach wrośniętych w pień i zaplątanych w konarach rękach. Beksiński przedstawia drzewo, którego korona przypomina szkielet. Kości nie są bezpośrednio odsłonięte, co można dostrzec, przyglądając się obciągniętym skórą stawom. Samo przedstawienie nie jest jednorodne, gdyż antropomorficzny kształt zachowuje jedynie część drzewa wyeksponowana na pierwszym planie, lepiej oświetlona. Najbardziej zacieniona część drzewa wygląda realistycznie, natomiast jaśniejsze fragmenty przyjmują trudne do jednoznacznego określenia, przejściowe, roślinno-zwierzęce kształty. Mimo statycznej ekspozycji obraz zdaje się przedstawiać metamorfozę drzewa-hybrydy. Co istotne, przejście

metafora, symbol, przestrzeń (zob. S. Wysłouch, Przestrzeń jako kategoria transdyscyplinarna, „Estetyka i Krytyka” 2009-2010, nr 17/18, s. 49-50). 
pomiędzy roślinną i zwierzęcą formą drzewa zachodzi za sprawą zmiany perspektywy. Drzewo prezentuje się jako roślina dopiero po chwili, gdy spojrzy się na zacienione gałęzie na drugim planie. Dzieje się to za sprawą percepcji patrzącego, który kieruje wzrok najpierw centralnie, ku oświetlonej części. Można powiedzieć, że ta antropomorficzna część drzewa zdaje się zbliżać ku oglądającemu, prosząc go o uwagę i dostrzeżenie jego odrębności od reszty skrytych $\mathrm{w}$ cieniu gałęzi. Wrażenie sięgania ku patrzącemu potęguje obecność kilku okrągłych kształtów, przypominających otwarte usta, uchwycone w niemym krzyku.

Beksiński konceptualizuje obecność patrzącego, angażując go emocjonalnie w los roślinno-zwierzęcej hybrydy, która niczym u Leśmiana, próbuje "się zjawić" i zaistnieć w ludzkiej świadomości, przeistaczając się w bardziej antropomorficzną, zwracającą uwagę formę. Możliwe jest to dzięki wyjątkowemu znaczeniu systemu percypowania twarzy wśród systemów przetwarzających bodźce wzrokowe, będącego konstruktem wrodzonym ${ }^{46}$. Z perspektywy filozoficznej można mówić o epifanii twarzy, która oznacza opisane przez Emmanuela Levinasa spotkanie z Innym. Zdaniem filozofa inność, której doświadcza rozmówca, wyrywa go ze świata, wzywa do siebie, stawia opór ${ }^{47}$. Schematyczny wyraz twarzy, który można dostrzec na obrazie Beksińskiego, wyraża krzyk, wołanie o pomoc, jednak pomimo tego, służącego wzbudzeniu empatii, komunikatu, za sprawą swojego monstrualnego, roślinno-zwierzęcego wyglądu, wywołać może strach i niechęć. Drzewo zmienia się w dziwną formę monstrum, stworzenia, które oczekując kontaktu, może wzbudzić grozę i nieufność.

Levinas konceptualizuje ludzką twarz jako byt, którego nie sposób odrzucić, będący wezwaniem, na które nie można nie odpowiedziećc ${ }^{4}$. Beksiński w swoim obrazie modyfikuje ten problem, pytając, czym jest twarz, co ją definiuje i czyni, jak to określa Levinas, nieredukowalną do rzeczy, a więc niepodległą mojej władzy, otwierającą na nieskończonośćt9. Odnosząc się do filozofii Levinasa, Jacques Derrida proponuje nieatropocentryczne spojrzenie na egzystencję istot nie-ludzkich. Poniekąd tematyzując również twarz i patrzenie, opowiada o spojrzeniu swojej kotki i podkreśla jej indywidualną egzystencje $e^{50}$. W świetle rozważań Derridy również monstrualna twarz, wychylająca się na obrazie Beksińskiego ku człowiekowi, zasługuje na uwagę.

Obraz Beksińskiego podejmuje zatem problem ludzkiego i nie-ludzkiego, odróżnienia twarzy od nie-twarzy i wynikające z tego konsekwencje etyczne. Malarz czyni to, konceptualizując obecność patrzącego

${ }^{46}$ E. Kamasz, Twarze i ich percepcja - kilka słów o tym, jak przetwarzamy ekspresję emocjonalna ludzkich twarzy, z uwzględnieniem roli wybranych cech osobowości w tym procesie, "Annales Universitatis Mariae Curie-Skłodowska. Lublin - Polonia" 2018, vol. XXXI, s. 4.

${ }^{47}$ E. Levinas, Całość i nieskończoność. Esej o zewnętrzności, przeł. M. Kowalska, Warszawa 1998, s. 227.

${ }^{48}$ Tamże, s. 236.

${ }^{49}$ Tamże, s. 232.

${ }^{50}$ J. Derrida, The Animal That Therefore I Am (More to Follow), "Critical Inquiry" 2002, vol. 28, no. 2. Zob. P. Szaj, Zwierze jako absolutny inny - otwieranie nie/możliwości, „Analiza i Egzystencja" 2016, nr 36. 
i mechanizmów percepcyjnych i empatii, przez co pokazuje człowieka jako podobną roślinno-zwierzęcemu drzewu hybrydę, w której nie sposób rozgraniczyć tego, co "naturalne”, i tego, co społeczne. Na nieoczekiwane wyzwanie twarzy wyrastającej z monstrualnego drzewa można odpowiedzieć w bardzo różny sposób, zarówno odrazą i odrzuceniem, jak też zainteresowaniem i empatią, upodmiotowiając ją lub urzeczowiając. Człowiek aspirując do miana jednostki odrębnej, wyrwanej siłą kultury ze świata zwierząt czy roślin, tworzy fałszywe wyobrażenie samego siebie. Tymczasem jego istota przypomina raczej przedstawianą przez Beksińskiego hybrydę, która, odpowiednio oświetlona, oglądana pod pewnych kątem, w różnych okolicznościach prezentuje się bardziej ludzko lub bardziej zwierzęco, o ile te stereotypowe rozróżnienia zachowują w przypadku jednorodnego, splątanego organizmu, takiego jak przedstawione drzewo, swój sens.

W wierszu Honeta pierwsze strofy nie pokazują pełni obrazu drzewa, choć tę tematykę sugeruje już sam tytuł. To on pomaga w rozpoznaniu dominanty semantycznej wiersza ${ }^{51}$, co, patrząc na samą treść, nie jest zadaniem łatwym, ze względu na wtrącane, oddalające od głównego tematu, obrazy poetyckie.

nagły błysk nożyc,

zajętych w mroku pracą nad długością barw,

drzewo w zimowym szepcie: kto was tak

odmienił? twarze wrośnięte w pień, zaplątane

w konarach ręce - za dużo zmarłych

jest $\mathrm{w}$ drzewie. las to kostnica, w której pada śnieg,

żeby oświetlić to, co utracili. krwiobieg

lśniący jak zegar w podwodnej świątyni,

drżenie owadów w kościach,

aby zapewnić ciału wdzięk i niepokój, gdy odchodzili, bezradnie

zaciskając pięści, bo właśnie trwały

żniwa, słońce czerwone jak kula,

w której odbywa się poród lub biczowanie - i głos, ten niepojęty,

powtarzał nad nimi: żyć. nie umierać

(drzewo przeludnione, bs, s. 74)

Opisując szczegóły drzewa, Honet sięga po porównanie „krwiobieg lśniący jak zegar w podwodnej świątyni", które wyraźnie odbiega semantycznie od dominanty, a służy jedynie podkreśleniu lśniącego, płynnego wyglądu drzewa. Wynika z tego oczywista różnica pomiędzy poezją Honeta i malarstwem Beksińskiego, w której dzieło rozwija się, zgodnie

\footnotetext{
${ }^{51}$ Seweryna Wysłouch analizuje rolę opisu w perspektywie wizualności literatury, dokonując przy tym typologii, w której jednym z rodzajów jest opis z dominantą semantyczną, którą odbiorca musi ustalić, aby odkryć, jakiego obiektu dotyczy. Zob. S. Wysłouch, Literatura a sztuki wizualne, Warszawa 1994, s. 31.
} 
z Przybosiową metaforą kwiatu, natomiast obraz stanowi gotowe przedstawienie. Obrazy w wierszu Honeta rzeczywiście rozgałęziają się, co pozwala mówić o obrazie w obrazie. Takie praktyki zdarzają się również w malarstwie, dosyć przypomnieć realistyczny obraz Arcyksiąże Leopold Wilhelm w swojej galerii w Brukseli (1651-1653) Davida Tienersa Młodszego czy surrealistyczne Oświecone przyjemności (1929) Salvadora Dalego. W przypadku porównania z malarstwem Beksińskiego, jeden wiersz Honeta można odnosić do wielu obrazów malarza. Przywoływane porównanie „krwiobieg lśniący jak zegar w podwodnej świątyni” jest realizacją motywu katedry, powtarzającego się zarówno w twórczości Honeta, jak i Beksińskiego:

ułożył bieg swej krwi w katedrę (bs, s. 10)

katedry kołyszące się w srebrnych płomieniach (m, s. 59)

psy i dzwony syczące w budach i katedrach ( $p k$, s. 26)

jakby bóg spawał katedrę w osłonie denaturatu ( $p k, \mathrm{~s} .38)$

Można w tym przypadku mówić o powtarzalności motywu, jednak jeden z obrazów Beksińskiego wskazuje na malarskie połączenie rozwijającego się obrazu poetyckiego w drzewie przeludnionym Honeta.

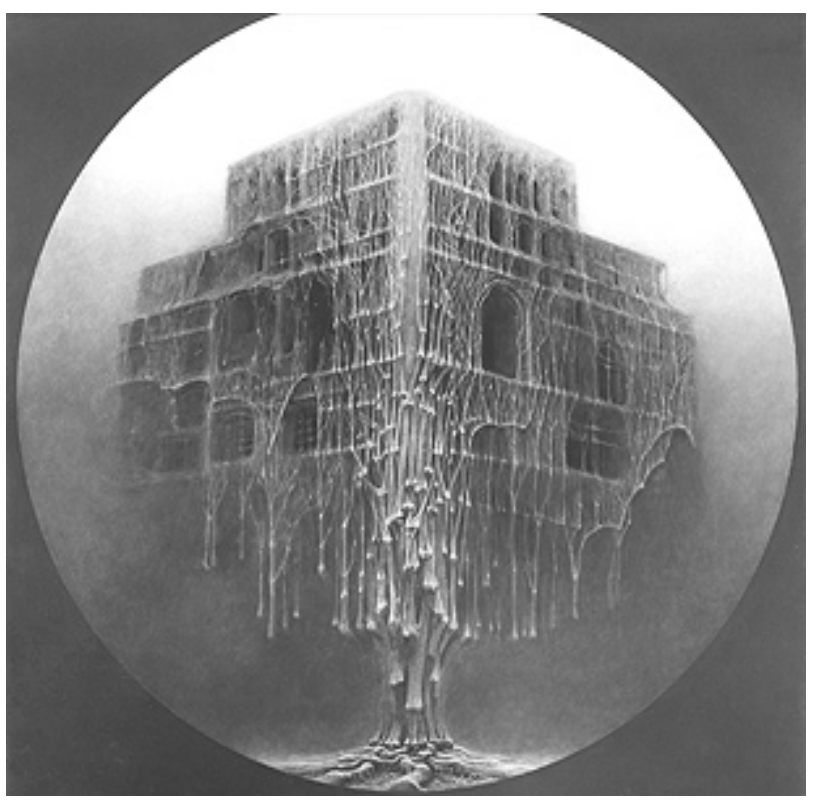

Ilustracja 4. [DG-3349], 1979-1980, olej na płycie pilśniowej, 87 x 87 cm

Przedstawienie świątyni i przedstawienie drzewa-hybrydy umieszczone są na planie koła, co zdarzało się Beksińskiemu bardzo rzadko. Na obu obrazach obiekty zostały oplecione roślinno-zwierzęcym pnączem z wyraźnie zaznaczonymi stawami kostnymi, którego kształt przypomina gałęzie drzewa omawianego obrazu (DG-2508). Kształt budowli, 
z niknącym we mgle fundamentem, przypomina drzewo, którego korzenie, czy też żyły, krzewią się po ziemi, kierując się w stronę oglądającego. Oplatający budowlę kształt, który obecny jest również na innych obrazach, uznać można za symboliczne połączenie między obrazami, zaświadczające o spójnym charakterze kreowanego przez Beksińskiego świata.

Pomimo rozwijanych piętrowo obrazów poetyckich w drzewie przeludnionym, Honet powraca do głównego tematu. Poeta anarchizuje swój opis, zaczynając od obrazu błysku nożyc, które „pracują w mroku nad długością barw", jak gdyby przycinały powstającą wizję do odpowiednich proporcji, by dać się jej rozwinąć w czasie. Honet pisze jedynie o „błysku” nożyc, które pracują w ciemności, dopiero w kolejnych strofach odsłaniając szczegóły przedstawianego drzewa. W obu dziełach istotna jest dynamika opisu, który skupia się na zmianę na szczególe i ogóle, pierwszym planie i tle, który pozwala różnicować kształty i podkreślić motyw przemiany. Na obrazie Beksińskiego widoczne jest to poprzez kontrastujące przedstawienie gałęzi znajdujących się $\mathrm{w}$ cieniu $\mathrm{z}$ tymi na pierwszym planie.

W wierszu Honeta motyw przemiany odczytać można z obrazu złączonych ludzkich zwłok z rośliną, o których monstrualnym wyglądzie zaświadcza retoryczne pytanie „kto was tak odmienił?”. W utworze poety przenikanie się tego, co ludzkie i nie-ludzkie, sproblematyzowane zostaje z innej perspektywy. Ostatnia strofa wskazuje na historyczne źródło całego obrazu. Wiszący na drzewie ludzie to ciężko pracujący na rachunek swojego pana chłopi. Nie sposób stwierdzić, czy inspiracją była ludowa historia Polski czy Stanów Zjednoczonych. Honet, inaczej niż Beksiński, koncentruje się na procesach następujących w ciele człowieka po jego śmierci, które prowadzą do jego metamorfozy nekrotycznej. Ewa Domańska w pracy $\mathrm{Ne}$ kros. Wprowadzenie do ontologii martwego ciała wskazuje między innymi na dendryfikację, czyli przemianę ciała w resztki, na których wyrasta roślina, zawierająca w sobie jego pierwiastki ${ }^{52}$. W drzewie przeludnionym Honet pisze o wcześniejszym etapie, na którym zaszła już w ciałach pewna przemiana, ale której daleko do dendryfikacji. Niemniej kreowane przez poetę sugestywne obrazy wrośniętych w pień twarzy, zaplątanych w konary rąk opowiadają o nekrotycznych metamorfozach i dalszych etapach istnienia człowieka po śmierci. Zarówno obraz poetycki Honeta, jak i obraz malarski Beksińskiego zdają się dotyczyć tego samego - związków biologicznego i duchowego trwania człowieka, jego relacji z tym, co nie-ludzkie. Honet zdaje się pytać, czy wrośnięta w pień twarz pozostaje twarzą, jak istnieje po śmierci, Beksiński natomiast zastanawia się, kiedy twarz staje się twarzą, czyli jak antropomorficzne staje się ludzkie.

Obrazy poetyckie, jakie pozostawia w czytelniku poezja Honeta, krystalizują się wraz z kolejnymi tomikami, nie sposób jednak zaprzeczyć, że proces konceptualizacji wspierają treści graficzne w postaci okładek książek. Na części z nich pojawiają grafiki, zwykle o melancholijnej symbolice, takie jak stare zdjęcia dzieci, na innych z kolei grafiki o proweniencji fantastycznej. Szczególnie sugestywne grafiki znalazły się na okładce tomu ciche

${ }^{52}$ E. Domańska, Nekros. Wprowadzenie do ontologii martwego ciała, Warszawa 2017, s. 11. 
psy, ostatniej jak dotąd książki poety. Ich autor, Jarek Kubicki, zdaje się wzorować na malarstwie Beksińskiego. Niezależnie od tych potwierdzonych przez to wydawnictwo skojarzeń z malarstwem, możliwa jest interpretacja porównawcza również wcześniejszych wierszy Honeta.

W artykule skupiłem się jedynie na kilku wybranych obszarach, rozwijając ogólne intuicje, wskazujące na podobieństwo między oboma twórcami. Widoczne jest ono w wykorzystaniu tanatycznego i turpistycznego obrazowania, monotematycznych tendencjach w użyciu pewnych motywów (u Honeta w postaci metamorfoz zwierzęco-somatycznych, a u Beksińskiego szczegółów anatomicznych i monumentalizmu), gotycyzmie, estetyce surrealistycznej, ekspresjonistycznej, onirycznej i groteskowej. Zestawienie ze sobą wierszy i obrazów ujawniło bardziej szczegółowe pokrewieństwo między oboma twórcami. Obaj metaforyzują procesy percepcyjne, wykorzystując je jako elementy znaczące, podporządkowane, w przypadku analizowanych utworów, refleksji nad nie-ludzkim życiem. Powtarzalność motywu przemiany i przedstawień hybrydycznych w twórczości artystów pozwala przypuszczać, że może to być temat ważny w całym dorobku. Przedstawione komentarze Honeta i Beksińskiego, dotyczące egzegetycznych interpretacji, treści i formy i znaczenia w ogóle, sugerują, że obaj postrzegają proces twórczy jako intuicyjny i wyobrażeniowy. Niejako wbrew zastrzeżeniom formułowanym przez obu twórców, obrazowość ich prac nie wyklucza obecności treści filozoficznych. Inspirujące okazują się odczytania włączające refleksję nad wyobraźnią, percepcją, empatią i somatycznością, jakim bez wątpienia są te dotyczące nie-ludzkiego życia.

\section{B I B L I O G R A F I A}

Bachelard G., Wyobraźnia poetycka. Wybór pism, przeł. H. Chudak, A. Tatarkiewicz, Warszawa 1975.

Banasiak J., Zdzistaw Beksiński jako totalne dzieło sztuki, „Szum”, https://magazynszum.pl/zdzislaw-beksinski-jako-totalne-dzielo-sztuki/ [dostęp 14.04.2021].

Beksiński Z., Beksinski on the Meaning of His Art, https://you.tube/1EsYHvVtb34?t=286/ [dostęp 30.04.2021].

Beksiński Z., Okrucieństwo? Pornografia? Sztuka?, „Kultura” 1974, nr 46.

Caillois R., W sercu fantastyki, przeł. M. Ochab, Gdańsk 2005.

Czekański G., Honet R., Milczenie, powrót, dzieciństwo, https://www.biuroliterackie.pl/biblioteka/wywiady/milczenie-powrot-smierc-dziecinstwo/ [dostęp 30.04.2021].

Czopik J., Beksiński Z., Sfotografować sen. Rozmowa ze Zdzistawem Beksińskim, "Tygodnik Kulturalny" 1978, nr 35.

Derrida J., The Animal That Therefore I Am (More to Follow), "Critical Inquiry" 2002, vol. 28, no. 2. https://doi.org/10.1086/449046 
Dmochowski P., Sale muzealne. Sala 10. Obrazy. Lata 1968-1983. Objaśnienie, http://beksinski.dmochowskigallery.net/galeria.php?artist=52 [dostęp 20.04.2021].

Domańska E., Nekros. Wprowadzenie do ontologii martwego ciała, Warszawa 2017.

Gorczyca Ł., Kaczyński M., Słowniczek artystyczny Rastra, http://raster.art.pl/ archiwa/slownik/slowniczek.htm [dostęp 14.04.2021].

Grodecka A., Fotografie nieistniejacego świata. O polskiej sztuce fantastycznej, „Poznańskie Studia Polonistyczne” 2016, nr 28 (48). https://doi. org/10.14746/pspsl.2016.28.3

Grzebałkowska M., Beksińscy. Portret podwójny, Kraków 2014.

Honet R., baw się, Wrocław 2009.

Honet R., ciche psy, Stronie Śląskie 2017.

Honet R., moja, Wrocław 2008.

Honet R., piąte królestwo, Wrocław 2011.

Honet R., świat był mój, Wrocław 2014.

Honet R., To ja posadzitem palmy $i$ wybrałem matpy. Z Romanem Honetem o książce piąte królestwo rozmawia Konrad Wojtyła, „biBLioteka. Magazyn Literacki", https://www.biuroliterackie.pl/biblioteka/wywiady/ to-ja-posadzilem-palmy-i-wybralem-malpy/ [dostęp 28.04.2021].

Ingarden R., Dwuwymiarowa budowa dzieła sztuki literackiej, [w:] R. Ingarden, Szkice z filozofii literatury, Kraków 2000.

Janowska K., Mucharski P., Beksiński Z., Beksiński about inner landscapes, 2002, https://youtu.be/MiYrn441P2U?t=77 [dostęp 28.04.2021].

Jarosz A., Beksiński i źródła wyobraźni, „Poznańskie Studia Polonistyczne” 2016, nr 28 (48). https://doi.org/10.14746/pspsl.2016.28.11

Jędrek G., Romana Honeta "świat był mój”, czyli uniwersum straty, [w:] Bowiem zmarli podróżuja szybko. Szkice o twórczości Romana Honeta, wyb., red. Z. Sala, Kraków 2020.

Jurzysta M., Jak i dlaczego ośmielała się wyobraźnia, [w:] Bowiem zmarli podróżuja szybko. Szkice o twórczości Romana Honeta, wyb., red. Z. Sala, Kraków 2020.

Jurzysta M., "Ośmielanie wyobraźni” w najnowszej poezji polskiej, [w:] Inne dwudziestolecie. Dwudziestolecie literackie 1989-2009, t. II, red. Z. Andres, J. Pasterski, Rzeszów 2010.

Kamasz E., Twarzei ich percepcja-kilka stów o tym, jakprzetwarzamy ekspresjęemocjonalna ludzkich twarzy, z uwzględnieniem roli wybranych cech osobowości w tym procesie, „Annales Universitatis Mariae Curie-Skłodowska. Lublin - Polonia" 2018, vol. XXXI. https://doi.org/10.17951/j.2018.31.4.307-322

Kopkiewicz A., Spóźniona zmysłowość i nowa wrażliwość (O "Przeciw interpretacji i innych esejach" Susan Sontag), „Wielogłos” 2012, nr 2 (12).

Korus Z., Zdzisław Beksiński, „Sound and Vision” 2001 (grudzień), nr 8.

Larek M., Dlaczego potrzebny jest nam Honet?, „biBLioteka. Magazyn Literacki", https://www.biuroliterackie.pl/biblioteka/recenzje/dlaczego-potrzebny-jest-nam-honet/ [dostęp 30.04.2021].

Levinas E., Całość i nieskończoność. Esej o zewnętrzności, przeł. M. Kowalska, Warszawa 1998. 
Maliszewski K., Głosy z „bezbrzeżnej podróży”, [w:] K. Maliszewski, Rozproszone głosy. Notatki krytyka, Warszawa 2006.

Materkowski F., Od wyzwolonej do ośmielonej wyobraźni, czyli o poetyce imaginatywistów polskich, [w:] Wyobraźnia poetycka XXI wieku, red. A. Czabanowska-Wróbel, M. Marchaj, Kraków 2014.

Niziołek M., Zdefiniować fantastyke, czyli "fantastyczne" (i nie tylko) teorie literatury fantastycznej, „Przestrzenie Teorii” 2005, nr 5.

Nycz R., Kulturowa natura, staby profesjonalizm. Kilka uwag o przedmiocie poznania literackiego i statusie dyskursu literaturoznawczego, [w:] Kulturowa teoria literatury, red. M.P. Markowski, R. Nycz, Kraków 2006.

Nyczek T., Zdzisław Beksiński, Warszawa 1989.

Orliński M., Sprawa wyobraźni, http://members.upcpoczta.pl/m.orlinski4/ sprawawyobrazni.htm [dostęp 30.03.2021].

Peroń M., Świat w rozkładzie. O nurcie „ośmielonej wyobraźni” roczników 70. (Roman Honet, Bartłomiej Majzel, Radosław Kobierski), [w:] Literatura na progu XXI wieku, red. J. Chłosta-Zielonka, Z. Chojnowski, Olsztyn 2014.

Rabizo-Birek M., Bruno Schulz poetów „ośmielonej wyobraźni” (preliminaria), „Schulz/Forum” 2019, nr 13. https://doi.org/10.26881/sf.2019.13.05

Ricoeur P., O interpretacji. Esej o Freudzie, przeł. M. Falski, Warszawa 2008.

Rottenberg A., Sztuka w Polsce 1945-2005, Warszawa 2005.

Sierszyński M., Genetycznie sensualna fantazja Honeta, „biBLioteka. Magazyn Literacki", https://www.biuroliterackie.pl/biblioteka/recenzje/genetycznie-sensualna-fantazja-honeta/ [dostęp 28.04.2021].

Skarzyńska M., Beksiński Z., Wszystko, co jest forma, może podlegać deformacji, „Akcent" 2006, nr 4.

Skurtys J., Krytyka negatywna (4): oślepła, „Mały Format” 2017, nr 9, http://malyformat.com/2017/09/krytyka-negatywna-4-oslepla/ [dostęp 14.04.2021].

Skurtys J., Wyobraź to sobie, „Wakat”, http://wakat.sdk.pl/wyobraz-to-sobie-sobie/ [dostęp 14.04.2021].

Skurtys J., Nowacki J., Niech im się śni po nocach, „Mały Format” 2019, nr 12. http://malyformat.com/2019/12/im-sie-sni-nocach/ [dostęp 14.04.2021].

Sontag S., Przeciw interpretacji, [w:] S. Sontag, Przeciw interpretacji $i$ inne eseje, przeł. M. Pasicka, A. Skucińska, D. Żukowski, Kraków 2012.

Stala M., Czy coś się zaczyna? Z Marianem Stalą o zjawisku najmłodszej polskiej poezji rozmawia P. Marecki, [w:] Tekstylia. O "rocznikach siedemdziesiątych", wyb. i oprac. P. Marecki, I. Stokfiszewski, M. Witkowski, Kraków 2002.

Stala M., Nocna alchemia, "Tygodnik Powszechny” 2008, nr 36.

Sternberg R.J., Psychologia poznawcza, przeł. E. Czerwińska, A. Matczak, Warszawa 2001.

Szaj P., Zwierze jako absolutny inny - otwieranie nie/możliwości, „Analiza i Egzystencja" 2016, nr 36. https://doi.org/10.18276/aie.2016.36-03

Taranienko Z., Znaczenie jest dla mnie bez znaczenia (Zdzisław Beksiński), [w:] Z. Taranienko, Rozmowy o malarstwie, Warszawa 1987.

Trusewicz S., Wyobraźnia wyzwolona i oko Romana Honeta, [w:] Wyobraźnia przestrzenna w perspektywie geopoetyki, red. E. Konończuk, K. Trusewicz, S. Trusewicz, Białystok 2018. 
Winiarski J., Te ciche spazmy o podartych włóknach, "Kwartalnik Artystyczny” 1997, nr 2.

Wysłouch S., Literatura a sztuki wizualne, Warszawa 1994.

Wysłouch S., Przestrzeń jako kategoria transdyscyplinarna, "Estetyka i Krytyka” 2009-2010, nr 17/18.

Wysłouch S., «Ut pictura poesis» - stara formula i nowe problemy, [w:] Ut pictura poesis, red. M. Skwara, S. Wysłouch, Gdańsk 2006.

Zeidler-Janiszewska A., "Visual Culture Studies” czy antropologicznie zorientowana Bildwissenschaft? O kierunkach zwrotu ikonicznego w naukach o kulturze, „Teksty Drugie” 2006, nr 4.

Szymon Trusewicz - dr, zatrudniony w Pracowni Teorii i Antropologii Literatury Kolegium Literaturoznawstwa Uniwersytetu w Białymstoku. Interesuje się polską poezją najnowszą, geopoetyką i wyobraźnią poetycką. Członek zespołu redakcyjnego „Białostockich Studiów Literaturoznawczych". Współredaktor monografii Wyobraźnia przestrzenna w perspektywie geopoetyki (2018), autor książki Poetyka przestrzeni geobiograficznej Eugeniusza Tkaczyszyna-Dyckiego (2021).

E-mail: s.trusewicz@uwb.edu.pl

\begin{tabular}{ll}
\hline Creative & $\begin{array}{l}\odot \text { by the author, licensee University of Lodz - Lodz University Press, Lodz, } \\
\text { Poland. This article is an open access article distributed under the terms and } \\
\text { conditions of the Creative Commons Attribution license CC-BY-NC-ND 4.0 } \\
\text { (https://creativecommons.org/licenses/by-nc-nd/4.0/) }\end{array}$ \\
\hline
\end{tabular} 